\title{
Is There a Future for Family Farming in West Africa?
}

\section{Camilla Toulmin and Bara Guèye*}

\section{Transformations in West African agriculture and family farming}

Agriculture is centrally important to the West African economy, providing 30-50 per cent of gross domestic product (GDP) in most countries, the major source of income and livelihoods for 70-80 per cent of the population, food supplies, and revenue from cash crop exports. Globally, the commitment of donors and governments to meeting the Millennium Development Goals (MDGs) has focused attention on the rural economy, where some 70 per cent of the world's poorest people live and work. Improving returns from agriculture has been identified as key to reaching poverty reduction targets. Understandably, therefore, governments in West Africa, as elsewhere, are interested in seeing how agriculture might be "modernised" to meet the many demands made of it.

West Africa exhibits a diverse array of family farms, in terms of size, assets, market orientation, income, diversification of activities, reliance on migrants' earnings and vulnerability to risk. Family farms in West Africa face a challenging future as local markets and food systems become increasingly globalised. This diversity of farming households and their differential ability to respond to market opportunities, invest in productive assets and meet their needs has led some observers to predict the end of the family farm. Those in favour of promoting

Table 1: Comparison Between Family Farms and Commercial Agriculture

\begin{tabular}{|c|c|c|}
\hline Characteristics & Family farms & Commercial agriculture \\
\hline Role of household labour & Major & Little or none \\
\hline Community linkages & $\begin{array}{l}\text { Strong - based on solidarity and } \\
\text { mutual help between household } \\
\text { and broader group }\end{array}$ & $\begin{array}{l}\text { Weak - often no social connection } \\
\text { between entrepreneur and local } \\
\text { community }\end{array}$ \\
\hline Priority objectives & $\begin{array}{l}\text { Consume } \\
\text { Stock } \\
\text { Sell }\end{array}$ & $\begin{array}{l}\text { Sell } \\
\text { Buy } \\
\text { Consume }\end{array}$ \\
\hline Diversification & High, to reduce exposure to risk & $\begin{array}{l}\text { Low, specialisation on very few crops } \\
\text { and activities }\end{array}$ \\
\hline Flexibility & High & Low \\
\hline Size of holding & Small, averaging 5-10 ha & Large, may exceed 100 ha \\
\hline Links to market & Weak but becoming stronger & Strong \\
\hline Land access & Inheritance and social arrangeme & Purchase \\
\hline
\end{tabular}

IDS Bulletin Vol 36 No 2 June 2005 @ Institute of Development Studies 
investment in large-scale commercial agribusiness can always find examples of impoverished, subsistence-oriented families, unable to cope with the multiple challenges of prices, climate and risk. Those seeking to demonstrate the dynamism and viability of family farms can point to a different set of smallholders who have clearly demonstrated their ability to address new markets and adopt new technologies. Policy measures need to consider how best to address the very different needs and pathways associated with each kind of producer, given their distinct strengths and challenges (see Table 1).

\section{Agricultural production: yields and harvests}

\subsection{Food crops}

Table 2 presents data for six West African countries on per capita production of major food crops since the 1960s, derived from Food and Agriculture Organization (FAO) statistics. Diversity between country experiences is clear, with Senegal and Niger sharing negative trends for major cereals (rice, millet, maize, sorghum) over the period, but Ghana, Nigeria, Mali and Côte d'Ivoire exhibiting more positive trends. For Ghana and Nigeria, a deep trough in production in the early 1980s resulted in growing dependence on imported food.
Subsequent policy shifts in favour of domestic agriculture provided greater incentives to farmers and a recovery in production levels followed. In the case of Niger, lying almost entirely in the Sahelian and Saharan zone, agriculture is particularly vulnerable to drought: cereal production was badly hit by the rainfall failures of 1973-5 and 1983-4. Nevertheless, evidence from southern Niger shows increasing output per capita and rising yields (Hamadou 2000). Growth in cowpea production was strongly positive, due largely to high levels of demand from neighbouring Nigeria. In Mali, all four cereals recovered strongly from a trough in 1981, this upward trend continuing for rice and maize, while faltering for millet and sorghum. In Côte d'Ivoire, per capita production of rice, maize and millet rose by 30 per cent over the period, although root and forest crop production declined by a similar percentage.

Comparable evidence is provided by a recent study of Burkina Faso, which shows that yields of the most important crops have increased considerably over the last 40 years (based on FAO data for 1961-98), despite a 20 per cent decline in rainfall. Rice and maize yields increased threefold, while yields for sorghum, millet and groundnuts doubled. Mazzucato et al. (2001: 6) conclude that:

Table 2: Change in Per Capita Production of Major Food Crops, 1961-3 to 1997-9

\begin{tabular}{llll}
\hline Country & Cereal crops & Root and forest crops & Change (\%) \\
\hline Ghana & Rice, maize, millet, sorghum & Cassava, yams, plantains & +59.8 \\
& & & +66.3 \\
Nigeria & Rice, maize, millet, sorghum & Cassava, yams, plantains & -1.2 \\
& & & +76.3 \\
Mali & Rice, maize, millet, sorghum & & -2.6 \\
Niger & Rice, millet & & -24.2 \\
& Cowpeas & & +131.2 \\
Côte d'Ivoire & Rice, maize, millet & Cassava, yams, bananas, plantains & +28.5 \\
& & & -41.2 \\
Senegal & Rice, maize, millet, sorghum & Cowpeas & +33.3 \\
\end{tabular}

Source: Mortimore (2003). 
Is There a Future for Family Farming in West Africa?

Table 3: Percentage Change in Primary Commodity World Prices, 1970-98

\begin{tabular}{lllll}
\hline & $\mathbf{1 9 7 0 - 8 0}$ & $\mathbf{1 9 8 0 - 9 0}$ & $\mathbf{1 9 9 0 - 8}$ & $\mathbf{1 9 8 0 - 9 8}$ \\
\hline Cotton & 13 & -36 & -24 & -51 \\
Cocoa & 35 & -65 & 27 & -55 \\
Coffee & 5 & -74 & 48 & -61 \\
Palm oil & -22 & -64 & 123 & -20 \\
\hline
\end{tabular}

Source: Kherallah et al. (2002).

While increased mechanisation, migration and fertiliser use have contributed to some degree to the increase in rice and maize yields, those are unlikely to be significant factors in the case of the other crops ... Farmers seem to have been able to even increase output without relying on external inputs to replenish soil fertility.

Thus the overall trends for food crop production show a remarkable degree of stability for some crops, and increases for others despite often adverse climate, economic and policy environments. Such performance is particularly striking when combined with data on the substantial growth in export crops.

\subsection{Export crops}

Table 3 shows the substantial decline in export crop prices for major commodities produced by West African agriculture, and sets the broader context for a discussion of farm performance.

\subsection{Cotton}

Cotton has been a major export commodity from West Africa for the last 50 years, where it is produced by an estimated six million smallholder households, on farms varying from 3-20 ha, mainly in Mali, Côte d'Ivoire, Benin, Chad and Burkina Faso. Substantial output growth over the last decade has seen a doubling in area cultivated and harvests between 1978/9 and 1988/9, with a further doubling to 1998/9 (Ton 2001). Cotton farmers are strongly affected by world market prices, which are currently at their lowest for 30 years - half the long-term average. This is the result of a large global harvest, generated in part by high subsidies paid to farmers in rich countries, combined with low levels of demand. Farmers in the USA and EU are protected from this price slump by high levels of producer support in the form of subsidies. By contrast, major losses in incomes and revenues have been felt by many developing country farmers, with no subsidies to protect them. Given that West African cotton production relies on smallholders, there is a clear contradiction between donor commitments to global poverty reduction and the subsidies donor countries pay to their own farmers.

\subsection{Cocoa}

Cocoa production in West Africa is mainly the business of Côte d'Ivoire and Ghana. As new producers have entered the world market from Latin America and East Asia (especially Vietnam and Indonesia), West African farmers no longer play a dominant role in global cocoa supplies. The current conflict in Côte d'Ivoire, which provided more than 40 per cent of world market supply in 2000, has provoked a substantial price hike, which benefited neighbouring Ghana as well as more distant producers.

Cocoa production in West Africa is produced mainly by smallholders - an estimated one million in Côte d'Ivoire and 800,000 in Ghana. There are a few large-scale plantations in both countries, but they represent a small percentage of total output. For Ghana, Konadu-Agyemang (2000) notes that while structural adjustment has brought improved incomes for some cocoa smallholders, large-scale producers have gained the lion's share. In the case of Côte d'Ivoire, the impacts of cocoa sector liberalisation combined with growing political tension have generated deep and damaging cuts in income, and a rapid rise in poverty in many parts of the country (Losch et al. 2003). It remains to be seen how the cocoa sector will re-establish itself when peace is achieved.

\subsection{Livestock production}

Although livestock numbers have grown throughout the region over the last 30-40 years (Mortimore 
2003), the index of livestock units per head of human population has remained broadly constant, implying a growth of 2-3 per cent per year. In general, livestock have shifted southwards into higher rainfall areas, with a larger proportion held by settled farming groups. Many former mobile herders are becoming sedentarised. Thus, the major part of the national herd in Mali is now found in the southern Sikasso region, where cattle provide valuable inputs into the local cotton farming system (traction, manure, assets). The proportion of sheep and goats has risen, these animals conferring greater resilience in the face of climate risk than cattle and camels, and offering prospects for lucrative fattening activities, as well as intensive milk and dairy production, around major towns and cities.

\subsection{Agricultural livelihoods and poverty}

Taking food and export crops together, many West African countries have been remarkably successful in raising output levels in response to market demand at national, regional and global levels. The farming sector evidently has great capacity to increase production, when conditions are right. This is even more marked taking into account the growth in many lesser crops for which data are not collected systematically, such as sheanut, sesame, fruit and vegetables (Wiggins 2000). As Guyer (1997: 4-5) notes for Nigeria:

Production and distribution systems have grown over the past several decades, and possibly at a rate which compares favourably with other historical cases even if not with the great spurt achieved in Asia through green revolution technologies. The food system has responded to demand despite difficulties of transport, no refrigeration, a narrow range of storage techniques and no commodity futures market ... the feeding of Nigerian towns across the great waves of macro-economic and political fluctuation has been an impressive achievement ...

The last $30-40$ years have shown more positive experiences than is admitted by those who assert that Africa's agriculture is in crisis. Despite periodic droughts, policy switches, devaluations and cutbacks in state support, farmers have managed to maintain growth in food production and kept pace with population growth, at the same time expanding exports of key commodities. Livestock numbers have also been maintained, with a growing level of integration between animal and crop production. Cropping patterns have shifted towards a more diverse range of commodities, from basic grains to maize, cowpeas, sesame and market gardening, in response to growing demand generated from expanding urban centres (Mortimore 2003; OECD 1998).

So, have rural West Africans become better off? The picture is mixed. While some farmers have done well and flourished, others have become poorer. Microlevel case material shows that many households have taken advantage of new opportunities, through allocations of family labour into migration and other activities. However, certain social groups have been particularly vulnerable to impoverishment. These include:

- households suffering a combination of misfortunes, such as harvest failure combined with illness within the family

- pastoral herders who suffered heavy livestock losses in the 1970s and 1980s and have been unable to re-stock, or to gain access to land for farming

- people with weak claims to land, including those in peri-urban areas who find themselves thrown off their plots as land values rise.

There are also cases where, due to major events such as civil conflict, large numbers of people find themselves substantially worse off than before. In Côte d'Ivoire, structural adjustment measures combined with collapsing world market prices and a breakdown in social and political cohesion led to a threefold increase between 1987 and 2002 in Ivoirians living below the poverty line (Losch et al. 2003). The subsequent period of escalating conflict brought a further rapid downward spiralling in incomes, livelihoods and security, except for those who have found new niches in a war-based economy.

\section{Large-scale farming and the "modernisation" of agriculture}

While farming in West Africa remains overwhelmingly in the hands of smallholders, governments in the region have consistently opted for policies of "agricultural modernisation". This involves promoting more secure forms of land tenure through changes in legislation to allow titling 
of land; allocating land concessions to large-scale farmers; and providing commercial farmers with preferential access to inputs and credit. In Ghana and Nigeria during the 1970s, for instance, governments encouraged foreign firms to invest in agriculture, but these efforts consistently failed (Guyer 1997). Similar difficulties were faced by commercial enterprises in Senegal. Large tracts of land and cheap credit were allocated to applicants, but the 1994 devaluation, combined with market liberalisation and restrictions on credit, led to the collapse of many commercial farms, unable to compete with smallholders and imports of cheap rice (Belières et al. 2002).

Meanwhile, government attitudes to smallholder agriculture vary: some assert the need to move away from small-scale farms, on the grounds that they can no longer cope with competition and technological change. Others, such as Senegal, explicitly commit themselves to support for family farms, while seeking to complement their presence with large-scale agro-industrial developments (Government of Senegal 2003). Senegal recently approved a project, 'Sénégal Agricole', which plans to put in place 25 large-scale agricultural schemes and half a dozen agro-poles, thereby adding 30,000 ha of irrigated land over five years (Walf Fajiri 2002).

Such projects appear to ignore the fact that there is no evidence in the West African context for the superiority of large-scale commercial agriculture, which has performed poorly over recent decades despite enjoying preferential access to inputs and output markets (Belières et al. 2002; Ouedraogo 2002; Toulmin 1992). By contrast, family farms have maintained a degree of autonomy and flexibility which has allowed them to cope with adverse circumstances and to adapt to emerging economic opportunities, using cheap labour in preference to costly credit and machinery.

\section{Prospects for West Africa's family farms: the next $10-20$ years} Looking forward, can family farms "feed the nation" and compete on global markets? Based on past experience, the answer is a qualified "yes" - but it depends. The future structure and performance of West Africa's farming sector will be the result of a number of factors, not all of which are in the hands of national decision-makers.
- Demand for staple food commodities is likely to grow, given current rates of income and population growth. Rising incomes will provide a more diversified market for a broader range of grains, fruit and vegetables, livestock produce and other higher value products. The strongest evidence that family farms will continue to satisfy these markets is the strength of recovery from stagnating food production in the 1980s. Economic incentives rather than capacity are the chief constraint, hence the importance of increasing the competitiveness of West African agriculture within the sub-region and ensuring protection from cheap imports.

- Resource pressures: Environmental challenges constitute a threat to continued growth in agricultural output. Although global climate models are not able to predict with any confidence future changes to weather patterns in the region, rising average temperatures seem certain, and these will bring increasing levels of evaporation. Farmers will need to manage water and soils with greater care. Rising demographic pressures, especially around major towns, will increase the scarcity and value of land. Governments must find ways to provide greater security over land, to encourage investment, ensure equitable access and reduce risks of conflict.

- Policy: There is a stark mismatch between commitment from Organisation for Economic Cooperation and Development (OECD) nations to meeting the MDGs, and current policies towards their own farming sector and trade regimes. African governments also face clear choices between the kinds of agriculture they wish to promote. Design of agricultural strategy is subject to lobbying and pressures from a range of internal and external actors. If the family farm is to continue as a central component of the agricultural sector, national farmer federations and producer organisations need to argue their case and challenge the view that "modernisation" necessarily means large commercial farms.

- Markets: The composition of West African farm production must continue to evolve in response to emerging markets for some products and falling returns for others. New niche markets offer promising alternatives, through fair trade, organic, or ethical trade initiatives. However, these schemes often present serious obstacles to smaller producers because of the transaction 
costs associated with joining. If smallholders are to benefit as a group, certification schemes must have promotion of "small farmers" as an explicit objective. Export agriculture has been promoted as the obvious escape route from economic stagnation in African countries. But this strategy makes no sense in the context of a long-term decline in the terms of trade for tropical commodities. Increased processing of primary commodities is key to adding value to exports as well as feeding into sub-regional markets. Continued pressure is needed for change to tariffs imposed by OECD nations for processed commodities, which would otherwise offer an important means of generating increased incomes and employment in poor countries.

Farmers' ability to respond to new opportunities and the challenges of globalisation are by no means

\section{Notes}

* This article draws from 'Transformations in West African agriculture and the role of family farming', Camilla Toulmin and Bara Guèye, Drylands Programme Issue Paper 123, London: International Institute for Environment and Development (IIED). The paper was prepared as a scoping study for the OECD's Sahel and West Africa Club Secretariat, to provide the basis for a longer term programme of work examining the transformations under way in West African agriculture, and the challenges faced by smallholder production systems. Preparation of the paper benefited from a grant from the Swedish International Development Cooperation Agency (Sida).

\section{References}

Belières, J.-F. Bosc, P.-M., Gaure, G., Fournier, S. and Losch, B., 2002, 'What future for West Africa's family farms in a world market economy?', Drylands Programme Issue Paper 113, London: International Institute for Environment and Development

Government of Senegal, 2003, Projet de loi d'orientation agricole, Dakar

Guyer J., 1997, An African Niche Economy: Farming to Feed Ibadan 1968-88, Edinburgh: Edinburgh University Press

Hamadou, S., 2000, 'Politiques nationales et investissement dans les petites exploitations à Maradi', Drylands Research Working Paper 33, Crewkerne: Drylands Research

Kherallah, M., Delgado, C., Gabre-Madhin, E., Minot, N. and Johnson, M., 2002, Reforming Agricultural Markets in Africa, Baltimore: assured. Farmers will continue to invest effort and capital in improving farm production where a reasonable return can be assured. But such returns are threatened by cheap imports, falling world market prices and difficulties in accessing credit and inputs. At the same time, policies in favour of agricultural modernisation appear to favour largescale producers at the expense of the millions of family farms which make up the current agricultural sector. Such favouritism is justified by policy-makers on the basis of family farms being unable to deliver a "modern" agricultural economy. Yet this position is based on a highly selective interpretation of available evidence, which ignores the strong commercial activities of many smallholders, and the great contributions they make to domestic food supplies and exports, as well as broader multifunctionality arguments in favour of promoting smallholder agriculture.
International Food Policy Research Institute and Johns Hopkins Press

Konadu-Agyemang, B., 2000, 'The best and the worst of times: structural adjustment programs and uneven development in Africa. The case of Ghana', Professional Geographer, Vol 52 No 3: 469-83

Losch B., Mesplé-Somps, S., Chauveau, J.-P., and Contamin, B., 2003, Le Processus de Liberalisation et la Crise Ivoirienne, Montpellier: Coopération Internationale en Recherche Agronomique pour le Développement and Developpement et Insertion Internationale (DIAL)

Mazzucato, V., Niemeijer, D., Stroosnijder, L. and Röling, N., 2001, 'Social networks and the dynamics of soil and water conservation in the Sahel', Gatekeeper Paper 101, London: International Institute for Environment and Development 
Mortimore, M., 2003, 'The future of family farms in West Africa: what can we learn from longterm data?', paper commissioned by International Institute for Environment and Development for the Organisation for Economic Cooperation and Development, London

OECD (Organisation for Economic Cooperation and Development), 1998, 'Preparing for the future. A vision of West Africa in the year 2020', West Africa Long Term Perspective Study, J.-M. Cour and S. Snrech (eds), Paris: Club du Sahel

Ouedraogo, M., 2002, Les Nouveaux Acteurs et la Promotion des Activites Agro-Sylvo-Pastorales dans le sud du Burkina Faso, London: International Institute for Environment and Development

Ton, P., 2001, Cotton Production and Rural Livelihoods in West Africa, Dakar: Oxfam

Toulmin, C., 1992, Cattle, Women and Wells. Managing Household Survival in the Sahel, Oxford: Clarendon Press

Walf Fajiri, No 3245, 6 janvier 2002, Dakar

Wiggins, S., 2000, 'Interpreting changes from the 1970s to the 1990s in African agriculture through village studies', World Development, Vol $28 \mathrm{No} 4$ 